\title{
Swajaldhara: 'Reversed' Realities in Rural Water Supply in India
}

\author{
Shilpi Srivastava*
}

\begin{abstract}
For the last two decades and more, nations, international organisations and civil society, both local and global, have been rallying for the cause of 'efficient' and 'equitable' water supply and distribution. To this end, the New Delhi Statement, a precursor to the Dublin Statement, in many ways marks the first step in reforming the water sector. This article explores how ideas of community ownership and participation lauded in the New Delhi Statement and reiterated in the Dublin Statement later translate into practice when they meet the complex sociopolitical and institutional realities at the ground. It locates the genesis of Swajaldhara, the flagship rural water reform programme in India, the origin of which can be traced to the Delhi-Dublin configuration and shows how a success model became a story of poor implementation defined in the language of 'gaps and slippages' or 'policy reversals'. It argues further that the objective of 'Some for All' still remains a target yet to be achieved in many parts of the country. The work underlines the disconnect between the global paradigms and local manifestations of such ideas and investigates the reasons for the same. Based on field research in two villages of the Indian state of Uttar Pradesh, the article unpacks the processes that lead to policy-practice dichotomy.
\end{abstract}

\begin{abstract}
1 Introduction
Despite decades of planning and water sector initiatives, rural water supply poses serious challenges in India with low coverage, serious water quality issues and unsustainability of the source. Prior to the 1990 s, water management had been the responsibility of state-owned public utilities. The State was recognised as trustee of these resources and the prime player in basic service delivery. A top-down, supply-led institutional structure, treated the end-users as mere beneficiaries and not direct participants in the decision-making process. The water sector reforms have shifted this locus of service delivery to other players such as private sector and local communities (Cullet 2007).
\end{abstract}

The International Drinking Water Supply and Sanitation Decade (1980-90), also known as the 'Water Decade', also recognised the limitations of the top-down approach to service delivery and encouraged participation by other stakeholders. In this context, the New Delhi Statement that in many ways marks the culmination of the decade, pressed for institutional reforms for an integrated management of water and specifically stressed the participation of community in the management of services, with special emphasis on the participation of women (United Nations 1990). The Dublin Statement (United Nations 1992) further reiterated the principle of community management and put a premium on water by declaring water as an economic good (UNCED 1992). It is this global context of institutional reform that provides the normative push for restructuring the rural drinking water sector in India.

This article critically investigates the objective of institutional reform through the principle of community management ${ }^{1}$ underlined in the New Delhi Statement and later the Dublin Statement and discusses the limitations of the reform process in the context of Swajaldhara. Following this introduction, the second section of the article explores how the reforms entered the lexicon of the Indian water policy discourse and states that an alignment at the policymaking level paved the way for the introduction and upscaling of the model. The third section highlights the policy practice dichotomy of the Swajaldhara experience against the complex realities of rural

IDS Bulletin Volume 43 Number 2 March 2012 (c) 2012 The Author. IDS Bulletin (c) 2012 Institute of Development Studies Published by Blackwell Publishing Ltd, 9600 Garsington Road, Oxford OX4 2DQ, UK and 350 Main Street, Malden, MA 02148, USA 
Uttar Pradesh. In conclusion, the experiences of Swajaldhara in the context of the objectives of the New Delhi Statement are assessed.

\section{Embedding Swajaldhara in the national water discourse}

Recognised as the flagship reform programme in the rural drinking water sector, Swajaldhara was launched on 25 December 2002 by the Prime Minister of the country, Mr Atal Behari Vajpayee. It was seen as the convergence of initiatives taken by the national government, non-governmental organisations (NGOs) and the external support agencies to promote the community-led participatory approach in rural drinking water supply initiative (GoI 2003). The programme underlined community participation in the planning and implementation phases. It introduced the concept of demand management, whereby the community will be able to 'choose' appropriate and affordable technology. ${ }^{2}$ It also placed user value on water through a 10 per cent community contribution in the planning phase and monthly water rentals to maintain the water infrastructure. It therefore marked a gradual shift towards the role of community participation and a decentralised pattern of service delivery, with the government playing the role of facilitator (World Bank 2006). A basic underlying assumption of the scheme was that cost sharing would enable participation and implementation of water asset ownership.

First, at the national level, there was persistent dissatisfaction with the supply-driven approaches. Throughout the Water Decade, several studies and review projects highlighted the drawbacks of technocratic systems, with problems of unsustainable technology and poor delivery systems. Lack of community ownership was highlighted as one of the major reasons for such failures (WWAP 2006). The Swajal project and the Sector Reform Initiative (1999), based on the principles of demand management, provided a positive backdrop and a viable institutional alternative to the inert structure of service delivery.

Second, the National Water Policy of 2002, stressed changes in the institutional mechanism in terms of a multi-sectoral, multidisciplinary and participatory approach, whereby 'existing institutions at various levels need to be appropriately re-oriented and re-organized'
(GoI 2002: 3). The policy also stressed the participatory approach to water resources management. It noted:

Management of water resources for diverse uses should incorporate a participatory approach; involving not only various governmental agencies but also stakeholders, in an effective and decisive manner, in various aspects of planning, design, development and management of water resources schemes (GoI 2002: 5).

Sangameswaran (2006) argues that there is a perceptive link between the national water policy discussions and the conventional wisdom that was reflected in the World Bank documents and the Swajal project concerning the user charges. These measures had considerable impact in the drafting of the tenth Five Year Plan (2002-07) document and the National Water Policy of 2002, which accepted the community pays principle (Nayar and James 2008).

Third, the deliberations at ministerial level, such as the Cochin Declaration in 1999, also ratified the alternative approach of community management; the states were willing to experiment with the idea of the demandresponsive approach in rural water supply (WSP 2000). Mr Venkaiah Naidu, Minister of Rural Development (2002), favoured reform in service delivery of rural water. Stressing the inefficiencies of the erstwhile supply-driven approach (Accelerated Rural Water Supply Programme, ARWSP), which was characterised by serious under-performance, he noted that a government run without the 'participation of stakeholders', where water is considered as a free service to be provided by the government, 'stifled' the development of more efficient, low-cost options for service delivery and denied users the right to demand better services (Naidu 2002).

Fourth, the presence of Panchayats (village governing body) as the third tier of governance provided effective institutional support for the inception of a decentralised model of community participation. For the government, the reform principle in Swajaldhara was actually aimed at strengthening the structure of local governance by generating robust institutions of service delivery (Naidu 2002). Community participation and local governance were not regarded as 
competing paradigms but were tied in a synergistic relationship, where empowered communities could help in effective rural governance.

The political mood in the country at the national and state level looked upbeat and positive in undertaking the new institutional mechanism of service delivery in the form of Swajaldhara. The political consensus helped in the up-scaling of the Sector Reform project into Swajaldhara in 2002.

\section{Policy meets practice: Swajaldhara in Bareilly} Uttar Pradesh is the most populous state in India. As per the population census of 2001, it accounts for 16 per cent of India's 102,702 crore population. Approximately 79 per cent of the population still lives in rural areas (GoI 2007). The rate of urbanisation, which is considered an indicator of development, has been slow in the state (Jha 2007). The Swajaldhara programme took place in Bareilly district in the Western region of the state. It was proposed in five villages but was only operational in two, Bhartaul and Chaneta, both located on the urban fringe. ${ }^{3}$ The programme was approved in 2004/05 and became operational in 2007. It was envisaged that the community should actively participate in the planning phase as well as the implementation of the programme. The local NGOs - support organisations (SOs) in this case - were chosen to facilitate community mobilisation and training.

\subsection{Participation}

The villagers identified the tank as the bada nal (big tap) or the tanki (tank). Very few villagers and some members of the committee were aware that a support organisation was involved in the process of establishing the scheme in their village. In Chaneta, the villagers knew that there was a pani ki tanki (water tank) in place but the logistics of its inception and introduction were seemingly unknown to them. Conversations with neighbours or villagers' proximity to the Gram Pradhan (head of the governing body) determined how informed they were about the proceedings in the village in general, and the tank in particular. Local patronage ties were effectively used in mobilising the rural population. This was visible in the process of generating demand for connections when the scheme was introduced. The operator at Bhartaul remarked that a number of meetings were held. However, not many villagers could remember a khuli (open) meeting when the scheme was introduced. Many of them were sceptical that a meeting had taken place, and one of the villagers said that the meeting was held behind closed doors and there was no consultation process.

This is significant, as the nature of information that was transferred to the villagers varied greatly. Most of them were aware that they had to contribute an amount of money to get a connection; however the process was determined not by them but by the key members in the sociopolitical set-up of the village. A resident in Bhartaul remarked over the issue of change in the rents: 'The poor people have no say: initially the rent was 15 rupees; who has made it to 30 rupees?'

The Village Water and Sanitation Committee (VWSC) is the committee of the Panchayat that oversees the programme in the village. Some villagers were not even aware that such a committee existed, and the members themselves didn't know that they were members of it. This was confirmed in my interview with the Gram Pradhan at Bhartaul when he pointed out that the 11 members of the committee were not aware of their membership. Either the members' names existed on paper only, or the members had chosen to disassociate themselves from the committee due to local politics and dissatisfaction with the committee.

Given the dominance of the Gram Pradhans in the landscape of the villages, they handled the operations of the committee. No meetings were held and any discussions held in the villages seemed to assume the decisions made by the Pradhan. The residence of the Pradhan at Bhartaul and the clinic in Chaneta had emerged as important sites of decision-making for the welfare of the villages. However, meetings were seemingly absent from the calendar of the Gram Panchayat.

The local practices and perceptions shaped the working of the VWSG and also the process through which Swajaldhara made its entry into the villages. In a context where participation was less understood as an inclusionary practice and more of a ceremonial exercise, it challenged the bottom-up notion of Swajaldhara from the start. The overarching role of the Gram Pradhan stunted 
the functioning of the VWSG, and not many villagers seemed dissatisfied with its lack of functioning.

\subsection{Community ownership}

The decentralised bottom-up approach of Swajaldhara was strongly embedded in the idea of community. The policy envisaged that once the villagers could relate to the water infrastructure as their own, they would be able to sustain and manage it. This idea arose as a strong counter to the top-down planning and implementation model. One of the serious lacunas that plagued the earlier policy models was that the users were treated more as subjects than participants in the process. In the context of Bareilly, where participation in the planning phase was minimal and there existed a high level of information asymmetry in the working of the committee itself, the idea of community appeared as mere fiction rather than reality.

\section{Who owns the tank?}

In a landscape ridden with information asymmetry at all levels, many villagers in Bhartaul and Chaneta did not treat the tank as their own. For them, it either belonged to the sarkar (government) or was the result of the efforts of a benign and concerned Gram Pradhan. In my field visits, the local people referred to Swajaldhara tank as the bada nal (big tap) or the sarkari nal (government's tap). The incentive for taking up the scheme was guided by economic reasons, as they were to pay less for the water connection than they usually had to pay under normal circumstances. ${ }^{5}$ For a tap connection under the Swajaldhara programme, the villagers had to pay 900 rupees in Bhartaul and 750 rupees in Chaneta, for which they would have previously paid approximately 3,000 rupees. This reduction of payment was the central point of mobilisation among the villagers.

The idea of a demand-driven scheme met with a paradox when the Gram Pradhan in Chaneta, regarding the inception of the scheme, told me that 'sarkari kaam-kaaj hai ... sab upar se hoke aata hai' (this is government's work, it gets done from above). In Chaneta, where there were fewer connections and water quality was a concern, villagers blamed the government for the dilapidated state of the infrastructure. There seemed to be an understanding that the government was to be held responsible for the mismanagement of affairs and they should do something about it.

The idea of community ownership was instituted to counter the traditional belief of patronage by the government and inculcate some feeling of stakeholder participation. However, in a context where people have relied on the government for basic services, the idea of management and ownership was starkly absent. The roots of the top-down model went deep enough to be countered by a singular idea of a demand-driven scheme of community ownership where the community was not even aware that they were the ones who had to maintain it.

\subsection{Paying for water?}

With an ambiguous idea of community in the local discourse of Swajaldhara, one could not avoid seeing problems associated with the lopsided view on collective action. In both villages, less than 50 per cent of the money was collected. This led to a maintenance deficit in the villages. Used to the top-down approach of service delivery, which Swajaldhara attempted to change but fell short of countering, many villagers thought that the tank belonged to the government and were not comfortable with the idea of paying for it.

Ambiguous rules and the fluid community of users had led to the emergence of a parallel group of free riders who were beneficiaries of the scheme but were not prepared to pay for water. The prevalence of these free riders dissuaded others from paying for their water. The issue of water quality in Chaneta made the water supply a valuable commodity. The households that could 'afford to pay' for water were doing so, since they had no recourse: 'Even if they ask us for 100 rupees, we will still have to pay, how can we stay without water?', replied an aaganwadi (basic health) worker in Chaneta. Households that had managed to get connections were deemed 'willing to pay' from their meagre resources. In Chaneta, despite quality concerns, poorer households could not afford to pay and used the poor quality water.

Some villagers expressed their anguish at the idea of paying for water. A resident in Chaneta stated that a number of people belong to the labour class and a large proportion of the population is below the poverty line and said, 
'You cannot expect them to pay'. The water supply in Chaneta also suffered from infrastructural problems, especially the intermittent supply of water due to recurring faults. This both discouraged willingness to pay and household ability to pay. Some people who already had connections were no longer willing to pay the rents in the absence of a water supply and instead used the 'yellow water'. This adversely affected the agenda of increasing connections, as most of the people perceived it as a failed investment.

\subsection{Where are the women?}

Women were identified as the key beneficiaries of the programme (GoI 2003). Policy documents gave due recognition to this fact and underlined the need for active participation of women in the working of the committee. However, the nonparticipation of women seemed to have been structured in the institutional implementation of the project. The State Water and Sanitation Mission (SWSM) personnel at Lucknow regarded it as too lofty an objective to be pursued, as this was seemingly impractical in the rural context of Uttar Pradesh. The policy implementers, quite aware of the patriarchal context, were not enthusiastic about the empowerment agenda within the policy. Within Swajaldhara, the mobilisation and participation of women was not visible in these two villages. Women were definitely the target users within the scheme but the patriarchal set-up of these villages prevented their full mobilisation. In Bhartaul, women managed to enter the discourse of Swajaldhara in the mobilisation phase but they were relegated to the private realm of the household once the tank was put in place. Their presence was instrumental in the phase of mobilisation but their participation in decision-making was absent.

\subsection{Role and accountability of the support organisations (SOs)}

The role of the SOs was to prepare and train the community to maintain the scheme. These organisations were engaged to give a participatory framework to the project. They were the channel of communication between the bureaucracy, i.e. the District Water and Sanitation Committee, the SWSM and the villagers. The SOs, given their proximity to the local context were delegated the responsibility for selecting the villages. After a field survey, a Detailed Project Report was prepared by them to be sent to the SWSM, to approve and release funds for the scheme.

The selection of villages was based on the ability to generate demand for new water schemes among the villagers. Most of the proposed villages were in close proximity to the city. The generation of demand rested on people's ability to agree to pay for the scheme. As stated earlier, not many villagers were aware of any organisation working in the village. The villagers in Bhartaul and Chaneta took them to be thekedaars (private operators) and their role as civil society actors was not visible in the local discourse. In Chaneta, the usual complaint was that SO personnel did not consult the people during their work and if the villagers raised any questions, they would be snubbed as being unaware and uneducated.

The attitude of the local bureaucracy and the SOs, when dealing with the villagers, was one of superiority and prejudice, reflecting their belief that villagers would not have the technical knowhow to maintain a tank. Moreover, it is interesting to note that the SOs were perceived to be a link between the villagers and the bureaucracy and seem to have been caught in a paradox where the bureaucracy treated them as the voice of the people whereas the villagers saw the SOs as an imposition from above.

\section{Conclusion}

The New Delhi Statement strongly emphasised community management beyond participation and stressed the need to develop linkages between national plans and community needs. However, the case study reflects a contradictory image of one-way traffic, where the idea of community ownership was channelled through a top-down process of bureaucratic delivery. Besides the local bureaucracy, it is also the role of NGOs - or here, the SOs - which needs to be critically investigated. Implanted in a context where the top-down model of service delivery was deeply embedded within the local institutions, the district level and the SO, the concept of demand-driven scheme and community ownership faced systemic reversals. The local practices of democracy and participation also influenced the process. The local institutions reconstructed the core ideas within Swajaldhara; these included concepts as such as participation and community ownership. Moreover, the 
practices of informal institutions such as patriarchy, patronage and local clientelism also shaped the implementation of the scheme.

The idea of community, which was strongly embedded in the policy discourse and was the bedrock of the flagship programme, did not hold strong by the time it reached the village - the potential and the intention had been filtered out. The community was still a group of beneficiaries who had to be supplied with water, rather than agents who could participate in the operation and maintenance of the scheme. Marginalised at the inception of the scheme, i.e. in the planning phase, the village community/user group was more in the status of subject beneficiaries than

\section{Notes}

* This article is based on the field research undertaken as part of the author's MPhil study at the Centre for the Study of Law and Governance, Jawaharlal Nehru University, India during 2008-09.

1 There has been a robust tradition of community management of water in the pre-reform era in India. The article analyses the reform induced principle of community management.

2 The approach of demand management was increasingly promoted by the World Bank to steer domestic water sector policies in various parts of the world, especially Asia and Africa (Joshi 2004). A major thrust in implementing demand responsive approaches in India came from the World Bank-UNDP Water and Sanitation Programme through the Swajal Project (1996-2002) that became the forerunner to Swajaldhara.

\section{References}

Cullet, P. (2007) Water Law in India: Overview of Existing Framework and Proposed Reforms, www.ielrc.org/content/w0701.pdf (accessed 14 September 2008)

Government of India (GoI) (2007) Uttar Pradesh Development Report, Vol. 1, New Delhi: Planning Commission of India

Government of India (GoI) (2003) Swajaldhara Guidelines, Ministry of Rural Development, http://megphed.gov.in/knowledge/schemes/ Swajguide.pdf (accessed 5 December 2011)

Government of India (GoI) (2002) National Water Policy, 2002, Ministry of Water Resources, www.indiawaterportal.org/data/policies/national _water_policy.pdf (accessed 12 February 2008) citizen participants. Although designed to be a bottom-up approach, Swajaldhara became embedded in a top-down model of service delivery and faced policy reversals. ${ }^{6}$

The case study discussed above shows how reforms that are articulated through global and national consensus face critical challenges on the ground. It stresses the need to take a more nuanced approach to the mechanisms of the frontline service delivery that include local bureaucracy. Support organisations and local governance structures are key to the reform process. It is this space that demands greater attention and possibly intervention to address and substantively extend the boundaries of 'Some for All'.

3 What makes these villages interesting is their peri-urban nature: both had a large population of retired army personnel who could afford to pay for water. This had strong implications for the selection of the villages in the initial stage.

4 Inference drawn from the interviews held with villagers.

5 Refers to the cost involved in installation of water pumps in the houses.

6 Following the reversals in the implementation of Swajaldhara, the Government of India revised the rural drinking water guidelines to the National Rural Drinking Water Programme. The document recognises water as a basic need and downplays the idea of charging for water see www.indiawaterportal.org/ sites/indiawaterportal.org/files/National \%20Rural\%20Drinking\%20Water\%20Program me_MoRD_2010.pdf).

Jha, S.N. (2007) Uttar Pradesh: The Land and the People, New Delhi: National Book Trust

Joshi, D. (2004) Secure Water - Whither Poverty? Livelihoods in the DRAs: A Case Study of the Water Supply Programme in India, London: Overseas Development Institute, www.odi.org.uk/ resources/docs/3850.pdf (accessed 5 December 2011)

Naidu, V. (2002) 'Indian Reform Initiatives in the Water Sector', keynote address delivered at the Water Forum, Washington DC, http:/ddws.gov.in/sites/upload_files/ddws/ files/pdf/pdf/MWForum.pdf (accessed 5 December 2011)

Nayar, V. and James, A.J. (2008) User Charges and Rural Water Supply: A Counter-Intuitive View from 
South India, www.un.org/esa/ffd/civilsociety/ msc/utilities_bangkok/vibhu_nayar_paper.pdf (accessed 23 March 2009)

Sangameswaran, P. (2006) Discourses in Water and Water Reform in Western India, www.ielrc.org/ activities/workshop_0612/content/d0616.pdf (accessed 1 December 2011)

UNGED (1992) Agenda 21, United Nations Conference on Environment and Development, 3-14 June 1992, Rio de Janeiro, Brazil, www.un.org/esa/dsd/agenda21/ (accessed 6 December 2011)

United Nations (1992) The Dublin Statement on Water and Sustainable Development, International Conference on Water and the Environment, Dublin, 31 January 1992, www.ielrc.org/content/e9209.pdf (accessed 1 December 2011)

United Nations (1990) New Delhi Statement, Global Consultation on Safe Water and Sanitation, 1990, www.ielrc.org/content/e9005.pdf (accessed 1 December 2011)

Water and Sanitation Program (WSP) (2000) Politicians for Reform: Proceedings of the State Water Ministers' Workshop on Rural Water Supply and Sanitation Reforms, Cochin, Kerala (India), 7-8 December 1999

World Bank (2006) Water Supply and Sanitation, Bridging the Gap between Infrastructure and Service, http://water.worldbank.org/water/publications/ india-water-supply-and-sanitation-bridginggap-between-infrastructure-and-service-urban (accessed 1 December 2011)

World Water Assessment Programme (WWAP) (2006) Water a Shared Responsibility: The United Nations World Water Development Report 2, Paris: United Nations Educational, Scientific and Cultural Organisation (UNESCO) 